\title{
Differential Patterns of Secreted Frizzled- Related Protein 4 (SFRP4) in Adipocyte Differentiation: Adipose Depot Specificity
}

\author{
Hua Guan ${ }^{a, b}$ Yali Zhang ${ }^{a, b}$ Shoucui Gao ${ }^{a, b} \quad$ Liang Bai ${ }^{a, b} \quad$ Sihai Zhao \\ Xian Wu Cheng ${ }^{c}$ Jianglin Fan ${ }^{d}$ Enqi Liu ${ }^{a, b}$ \\ aResearch Institute of Atherosclerotic Disease, Xi'an Jiaotong University Cardiovascular Research \\ Center, Xi'an, Shaanxi, 'Laboratory Animal Center, Xi'an Jiaotong University Health Science Center, \\ Xi'an, Shaanxi, 'Department of Cardiology, Yanbian University Hospital, Yanji, Jilin, China, 'Department \\ of Molecular Pathology, Faculty of Medicine, Graduate School of Medical Sciences, University of \\ Yamanashi, Yamanashi, Japan
}

\section{Key Words}

Sfrp4 $\cdot$ Adipocyte differentiation - Subcutaneous fat • Visceral fat

\begin{abstract}
Background/Aims: Secreted frizzled-related protein 4 (SFRP4) is a member of the SFRP family that acts as soluble modulators of Wnt signaling. Given the substantial rise in obesity, depot-specific fat accumulation and its associated diseases like diabetes, it is important to understand the molecular basis of depot-specific adipocyte differentiation. In the current study, we investigated the expression of SFRP4 in both subcutaneous and visceral adipose tissue in terms of their differentiation. Methods: White preadipocytes were isolated from the inguinal white adipose tissue (iWAT) and epididymal white adipose tissue (eWAT) from C57BL/6J mice (age: 8-week-old, male). SFRP4 expression in iWAT and eWAT preadipocytes was silenced by siRNA transfection and harvested cells for gene and protein expression analysis was performed during the differentiation. Furthermore, iWAT and eWAT preadipocytes treated with or without IL-1 $\beta$ were harvested for gene and protein expression analysis. Results: SFRP4 expression levels were gradually increased and proportionally associated with eWAT adipocyte differentiation toward maturation at 14 days, while iWAT adipocyte just showed an opposite tendency. Moreover, genetic (adiponectin, C/EBP $\alpha, C / E B P \beta, F A B P 4$, GLUT4 and PPAR $\gamma$ ) analysis demonstrated that depot-specific adipogenesis in response to SFRP4 silencing in eWAT and iWAT preadipocytes. Upon IL-1 $\beta$ treatment, SFRP4 mRNA expression decreased significantly in iWAT adipocyte, but the expression was no significant difference in eWAT adipocyte. Conclusion: These results suggest that SFRP4 expression differentially mediates adipocyte differentiation and may play an important role in adipogenesis.
\end{abstract}




\section{Cellular Physiology Cell Physiol Biochem 2018;46:2149-2164 and Biochemistry Published online: May 06, $2018 \quad \begin{aligned} & \text { DOI 10159/2018 The Author(s). Published by S. Karger AG, Basel } \\ & \text { www.karger.com/cpb }\end{aligned}$ Guan et al.: SFRP4 in Adipocyte Dedifferentiation}

\section{Introduction}

Obesity represents a major global health problem. Adipose tissue dysfunction underpins the association of obesity with the development of chronic metabolic diseases, including type 2 diabetes [1]. Thus, research into the molecular and cellular mechanisms governing the maintenance of adipose tissue mass and function is critical for the development of effective therapeutic strategies aimed at reducing obesity-related diseases [2]. Adipose tissue is restricted to certain areas in the body and its growth is a result of preadipocyte hyperplasia (increase in number) and hypertrophy (increase in size) [3]. Adipose tissue can be found in areas composed of loose connective tissues, such as the subcutaneous layer between muscle and dermis. Fat depots can also be found around inner organs and in the muscle tissue, known as visceral and intramuscular fat, respectively [4]. Interestingly, preadipocytes in different fat depots seem to have distinct adipogenic potential, and the metabolic activity differs between mature adipocytes of various depot origins [5].

Secreted frizzled related protein 4 (SFRP4) is a member of the SFRP family that contains a cysteine-rich domain homologous to the putative Wnt-binding site of frizzled proteins [6]. SFRPs act as soluble modulators of Wnt signaling, which block Wnt signaling either by working as a decoy receptor for Wnt ligands or by forming non-functional complexes with frizzled receptors [7-9]. We previously reported that compared with lean animals SFRP4 gene expression is elevated in the adipose tissue of obese animals [10]; this result indicated that SFRP4 expression levels are markedly elevated during the differentiation of preadipocytes into mature adipocytes. In addition, SFRP4 has been shown to affect preadipocyte differentiation in human adipose tissue-derived mesenchymal stem cells through the Wnt/ $\beta$-catenin signaling pathway $[11,12]$. Moreover, SFRP4 expression was increased in the visceral adipose tissue from obese individuals and is associated with insulin resistance [13]. Later, studies demonstrated that serum SFRP4 levels are inversely correlated with the first phase of glucose-stimulated insulin secretion in individuals with different glucose tolerance [14]. Consistent with these data, SFRP4 has been reported to be overexpressed in islets of patients with type 2 diabetes and to reduce glucose tolerance and insulin secretion in humans $[15,16]$.

The existence of intrinsic, fat depot-specific functional differences in both humans and animal models has been strongly supported by the differential gene expression of adipokines; in contrast, differences in the expression of mouse SFRP4 in subcutaneous vs. visceral adipose tissue adipocytes have not been well characterized. This study examined the effect of SFRP4 on the subcutaneous and visceral adipose tissue adipocyte differentiation in mice. We determined whether (1) there were site-specific differences in SFRP4 expression between subcutaneous and visceral adipose tissue adipocyte differentiation; (2) whether the adipose tissue expression of SFRP4 was related to lipid accumulation in adiposity; and (3) whether subcutaneous and visceral adipose tissue adipocyte SFRP4 expression was stimulated by the inflammatory factor interleukin-1 beta (IL-1 $\beta$ ).

\section{Materials and Methods}

\section{White preadipocyte isolation and culture}

White preadipocytes were isolated from the inguinal white adipose tissue (iWAT) and epididymal white adipose tissue (eWAT) (age: 8-week-old C57BL/6J mice. Body weight: 20-22g). iWAT and eWAT were isolated from 20 mice according to the established method [17, 18]. In brief, adipose tissues were collected from the epididymis or inguinal region of mice under sterile conditions, and washed in phosphatebuffered saline for three times. The tissue mass was cut with scissors into approximately $1 \mathrm{~mm}^{3}$ sections and digested with $1 \mathrm{mg} / \mathrm{mL}$ type I collagenase at $37^{\circ} \mathrm{C}$ for $40 \mathrm{~min}$ in a shaking water bath. Then, Dulbecco's modified Eagle's medium/nutrient mixture F-12 (DMEM/F12) medium containing 10\% FBS was added to stop digestion. To remove undigested tissue fragments and large cell aggregates, digested tissue suspension was filtered through $200 \mu \mathrm{m}$ nylon mesh. The stromal vascular fraction was collected by centrifugation at 


\section{Cellular Physiology Cell Physiol Biochem 2018;46:2149-2164 \begin{tabular}{ll|l} 
and Biochemistry $10.1159 / 000489545$ & $\begin{array}{l}\text { Dublished online: May 06, } 2018 \\
\text { www.karger.com/cpb }\end{array}$ \\
\hline
\end{tabular}

$800 \times \mathrm{g}$ for $5 \mathrm{~min}$ and then treated with red cell lysis buffer ( $154 \mathrm{mM} \mathrm{NH}_{4} \mathrm{Cl}, 10 \mathrm{mM} \mathrm{KHCO}{ }_{3}, 0.1 \mathrm{mM}$ EDTA) for $5 \mathrm{~min}$ at room temperature. The stromal vascular fraction cell pellet was collected by centrifugation and washed twice with serum free medium. Then, the cells were resuspended with DMEM/F12 supplemented with $10 \%$ fetal bovine serum and $1 \%$ Pen/Strep. Finally, the cells were seeded in culture dishes at a density of $5 \times 10^{4}$ cells $/ \mathrm{cm}^{2}$ and cultured at $37^{\circ} \mathrm{C}$ in humidified atmosphere with $5 \% \mathrm{CO}_{2}$. For white adipocyte in vitro differentiation, fully confluent cells were kept in 10\% FBS DMEM/F12 growth medium for 2 days and then treated with induction medium supplemented with $20 \mathrm{nM}$ insulin, $1 \mathrm{nM}$ triiodothyronine, $0.25 \mu \mathrm{M}$ dexamethasone, $0.5 \mathrm{mM}$ isobutylmethylxanthine, and $1 \mu \mathrm{M}$ rosiglitazone. After 3 days, the cells were kept in medium supplemented with $20 \mathrm{nM}$ insulin and $1 \mathrm{nM}$ triiodothyronine for 3 to 6 days. Medium was exchanged every 2 days. White adipocyte differentiation pattern was shown in Fig. 1A. The animal experimental protocol was approved by the Laboratory Animal Administration Committee of Xi'an Jiaotong University and carried out according to the Guidelines for Animal Experimentation of Xi'an Jiaotong University and the Guide for the Care and Use of Laboratory Animals published by the US National Institutes of Health (NIH Publication number 85-23, revised 2011).

\section{qRT-PCR analysis}

Total RNA from adipocytes was extracted using TRIzol Plus (Invitrogen, Carlsbad, CA, USA), and cDNA was synthesized with a SuperScript ${ }^{\circledR}$ III First-Strand Synthesis System (Invitrogen, Carlsbad, CA, USA). qRT-PCR analysis was performed using TaKaRa TP800 (TaKaRa Biology Inc., Shiga, Japan). The number of transcripts was quantified, and each sample was normalized according to its $\beta$-actin content. Relative expression of the gene of interest was determined using $\beta$-actin as the housekeeping gene using the calculation $=2^{\text {(ct } \beta \text {-actin gene }-C t \text { gene of interest) }}$. All the qRT-PCR experiments were performed in accordance with the MIQE guidelines [19]. The PCR primer sequences are shown in Table 1.

\section{Western blotting analysis}

Adipocyte samples were homogenized in lysis buffer (HEPES 50 mM; NaCl 150 mM; Triton X-100 1\%;

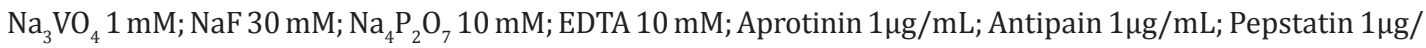
$\mathrm{mL}$; Leupeptin $1 \mu \mathrm{g} / \mathrm{mL}$; Benzamidine $2.5 \mathrm{mM}$; AEBSF $0.5 \mathrm{mM}, \mathrm{pH}=7.4$ ) at $4^{\circ} \mathrm{C}$. The resultant supernatants were subjected to Western blotting. Briefly, $30 \mu \mathrm{g}$ of lysate was fractionated on $10 \%$ SDS-polyacrylamide gels and then transferred to Sequi-blotting polyvinylidene fluoride membranes (Bio-Rad, Hercules, CA,

Fig. 1. Protocols for inducing white adipocyte differentiation and secreted related protein 4 (SFRP4) siRNA interference methods. (A) For white adipocyte in vitro differentiation, fully confluent cells were kept in growth medium for 2 days and then treated with induction medium supplemented with 20 $\mathrm{nM}$ insulin, $1 \mathrm{nM}$ triiodothyronine, $0.25 \mu \mathrm{M}$ dexamethasone, $0.5 \mathrm{mM}$ isobutylmethylxanthine, and $1 \mu \mathrm{M}$ rosiglitazone. After 3 days, the cells were kept in medium supplemented with $20 \mathrm{nM}$ insulin and $1 \mathrm{nM}$ triiodothyronine for 3 to 6 days. Medium was exchanged every 2 days. (B) Preadipocytes were grown on six-well plates until they reached 50-80\% confluence. The siRNA solution mixed with antibiotic-free 10\% FBS DMEM/F12 containing NanoJuice Transfection reagents was added to each well to achieve a final siRNA concentration of $50 \mathrm{nM}$. Knockdown efficiency was assessed $72 \mathrm{~h}$ posttransfection by RT-PCR and Western blotting.

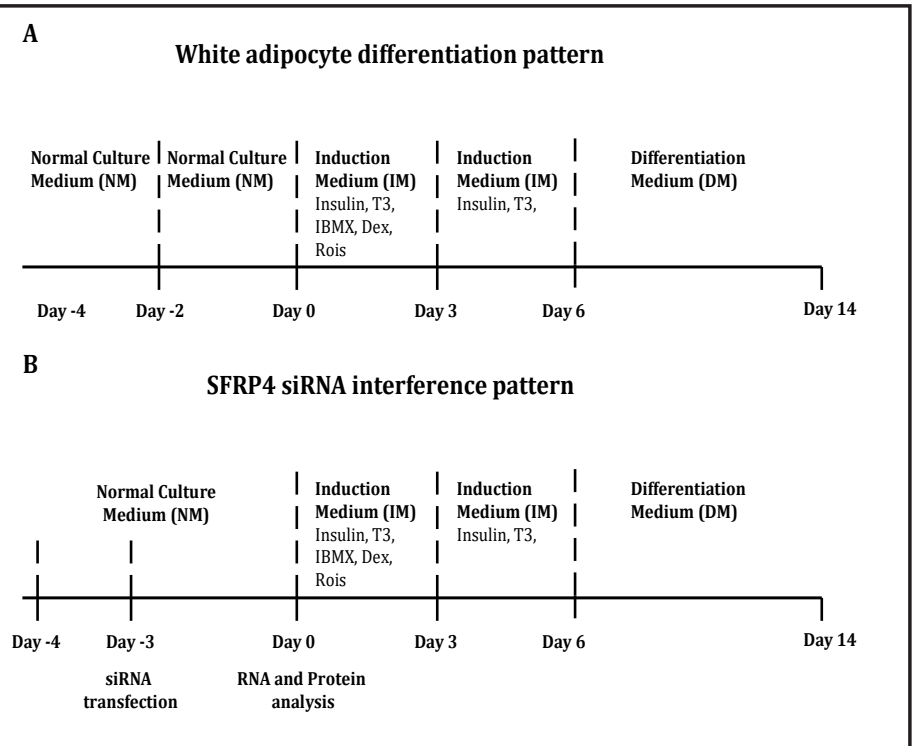




\section{Cellular Physiology Cell Physiol Biochem 2018;46:2149-2164 \begin{tabular}{ll|l} 
DOI: $10.1159 / 000489545$ & \\
and Biochemistry & $\begin{array}{l}\text { Published online: May 06, } 2018 \\
\text { www.karger.com/cpb }\end{array}$ \\
\cline { 1 - 2 }
\end{tabular}

Table 1. Primers used for real-time RT-PCR

\begin{tabular}{|c|c|c|c|}
\hline Genes & $\begin{array}{c}\text { Accession } \\
\text { Number }\end{array}$ & & Sequences ( $\left.5^{\prime}-3^{\prime}\right)$ \\
\hline \multirow{2}{*}{ Adiponectin } & \multirow{2}{*}{ NM_009605 } & Reverse & TTCTGTCTGTACGATTGTCAGTGG \\
\hline & & Forward & GTCATCTTCGGCATGACTGG \\
\hline \multirow{2}{*}{$\beta$-actin } & \multirow{2}{*}{ NM_007393 } & Reverse & GCGGCATCCACGAAACTAC \\
\hline & & Forward & TGATCTCCTTCTGCATCCTGTC \\
\hline \multirow{2}{*}{$\beta$-catenin } & \multirow{2}{*}{ NM_001165902 } & Reverse & CCTAGCTGGTGGACTGCAGAA \\
\hline & & Forward & CACCACTGGCCAGAATGATGA \\
\hline \multirow{2}{*}{$\mathrm{C} / \mathrm{EBP} \alpha$} & \multirow{2}{*}{ NM_001287523 } & Reverse & TTGAAGCACAATCGATCCATCC \\
\hline & & Forward & GCACACTGCCATTGCACAAG \\
\hline \multirow{2}{*}{$\mathrm{C} / \mathrm{EBP} \beta$} & \multirow{2}{*}{ NM_001287739 } & Reverse & ACCGGGTTTCGGGACTTGA \\
\hline & & Forward & CCCGCAGGAACATCTTTAAGTGA \\
\hline \multirow{2}{*}{ c-Myc } & \multirow{2}{*}{ NM_001177352 } & Reverse & AATCCTGTACCTCGTCCGATTCC \\
\hline & & Forward & СТСТTСТССАСАGАСАССАСАТСАА \\
\hline \multirow{2}{*}{ Cyclin D1 } & \multirow{2}{*}{ NM_007631 } & Reverse & TGTTCGTGGCCTCTAAGATGAAG \\
\hline & & Forward & GGAAGTGTTCGATGAAATCGTG \\
\hline \multirow{2}{*}{ Perilipin 2} & \multirow{2}{*}{ NM_007408 } & Reverse & GATTGAATTCGCCAGGAAGA \\
\hline & & Forward & TGGCATGTAGTCTGGAGCTG \\
\hline \multirow{2}{*}{ MCP-1 } & \multirow{2}{*}{ NM_011333 } & Reverse & AGCAGCAGGTGTCCCAAAGA \\
\hline & & Forward & GTGCTGAAGACCTTAGGGCAGA \\
\hline \multirow{2}{*}{ PPAR $\gamma$} & \multirow{2}{*}{ NM_001127330 } & Reverse & GGAGCCTAAGTTTGAGTTTGCTGTG \\
\hline & & Forward & TGCAGCAGGTTGTCTTGGATG \\
\hline \multirow{2}{*}{ SFRP4 } & \multirow{2}{*}{ NM_016687 } & Reverse & AAGCCGACCCTGGCAACATA \\
\hline & & Forward & TTGTGACCTCATTGCAACCACTC \\
\hline \multirow{2}{*}{ TCF4 } & \multirow{2}{*}{ NM_001083967 } & Reverse & AGGTTCCGGTCCCACAACTTC \\
\hline & & Forward & CGGATTTGATCTCAGAGCTACCA \\
\hline \multirow{2}{*}{ TNF- $\alpha$} & \multirow{2}{*}{ NM_001278601 } & Reverse & TATGGCCCAGACCCTCACA \\
\hline & & Forward & GGAGTAGACAAGGTACAACCCATC \\
\hline \multirow{2}{*}{ IL-6 } & \multirow{2}{*}{ NM_001314054 } & Reverse & CCACTTCACAAGTCGGAGGCTTA \\
\hline & & Forward & CCAGTTTGGTAGCATCCATCATTTC \\
\hline \multirow{2}{*}{ Wnt3a } & & Reverse & CTGGCAGCTGTGAAGTGAAG \\
\hline & NIVI_OUצכל & Forward & TGGGTGAGGCCTCGTAGTAG \\
\hline WInt5 5 & NM 001256105 & Reverse & CAAATAGGCAGCCGAGAGAC \\
\hline Whitsa & 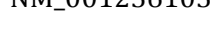 & Forward & CTCTAGCGTCCACGAACTCC \\
\hline Wint77 & NM 009527 & Reverse & GGTGCGAGCATCATCTGTAA \\
\hline Wvilid & INIVI_00952 & Forward & TCCTTCCCGAAGACAGTACG \\
\hline Wht11 & NM 001285792 & Reverse & CAGGATCCCAAGCCAATAAA \\
\hline 佂 & 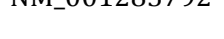 & Forward & GTAGCGGGTCTTGAGGTCAG \\
\hline
\end{tabular}

USA). Blotting membranes were incubated with primary antibodies (Abs) against SFRP4 1:1000 (Cat. No. 15328, Proteintech), adiponectin 1:1000 (Cat. No. AF1119, R\&D), leptin 1:1000 (Cat. No. AF498, R\&D), fatty acid binding protein 4 (FABP4) 1:1000 (Cat. No. AF1443, R\&D), CCAAT/enhancer-binding protein alpha (C/EBP $\alpha$ ) 1:500 (Cat. No. ab40764, Abcam), IL-1 1:1000 (Cat. No. ab9722, Abcam), $\beta$-catenin 1:2000 (Cat. No. ab2365, Abcam), $\beta$-tubulin 1:2000(Cat. No. ab15246, Abcam) at $4^{\circ} \mathrm{C}$ overnight, as recommended in the manufacturer's instructions. After washing (3X), the membranes were incubated with horseradish peroxidase-conjugated secondary $\mathrm{Ab}$ 1:5000 for $2 \mathrm{~h}$. Signals were detected using the immobilon reagent 
(Millipore, Billerica, MA, USA) and visualized using an LAS-400 Lumino image analyzer (Fujifilm, Co., Tokyo). Visualized signal intensities were quantitatively analyzed using MultiGauge software (Bio-Rad, Hercules, CA, USA). All secondary Abs were purchased from Cell Signaling Technology (Beverly, MA, USA).

\section{SFRP4 knockdown}

SFRP4 small interfering RNA (siRNA) and negative control (NC) siRNA were purchased from RiboBio (Guangzhou, China) (siRNA sequences are shown in Table 2.). In pioneer study, we designed and tested three SFRP4 siRNA sequences and chose siRNA3 for the following experiments because of the strongest knockdown activity (data not shown). Preadipocytes were grown on six-well plates until they reached $50-80 \%$ confluence. The siRNA solution mixed with antibiotic-free Opti-MEM containing NanoJuice Transfection reagents (Millipore, Billerica, MA, USA) was added to each well to achieve a final siRNA concentration of $50 \mathrm{nM}$. Knockdown was assessed $72 \mathrm{~h}$ post-transfection by real-time RT-PCR and Western blotting. Transfected cells were then cultured in serum-containing medium for an additional 3 days before the induction of differentiation under standard differentiation conditions. At differentiation days 0, 7 or 14, cells were harvested for subsequent analysis. Protocol for SFRP4 siRNA interference was shown in Fig. 1B.

\section{IL-1 $\beta$ treatment}

White preadipocytes isolated from the eWAT and iWAT as above were treated with recombinant mouse IL-1 $\beta$ active protein (Sino Biological Company, Beijing, China) at $25 \mathrm{ng} / \mathrm{mL}$ for indicated the time points as described previously [15].

\section{Oil Red 0 staining}

Dishes were washed twice with phosphate-buffered saline and fixed with $10 \%$ buffered formalin for at least $1 \mathrm{~h}$ at room temperature. Cells were then stained for $2 \mathrm{~h}$ at room temperature with a filtered Oil Red O solution ( $0.5 \%$ Oil Red 0 in isopropyl alcohol), washed twice with distilled water, and observed under a light microscope. Oil Red 0 staining area was quantified by the image analysis system (WinRoof Mitani Co., Tokyo, Japan) [20].

\section{Statistical analysis}

All data are expressed as the mean \pm SEM. Statistical analyses were performed using either Student's $t$-test with an equal $F$ value or Welch's $t$ test when the $F$ value was not equal. Data from three groups were analyzed by one-way ANVOA, followed by Tukey's multiple-comparison procedure. For unequal variances, data were evaluated by the Kruskal-Wallis test. Statistical significance was determined to be reached at a $P$-value of less than 0.05 .

\section{Results}

Expression pattern of SFRP4 in eWAT adipocyte differentiation

eWAT preadipocytes were induced to differentiate into mature adipocytes. Our data showed that at 2 days post confluence, growth-arrested eWAT preadipocytes were induced into mature adipocytes; we measured SFRP4 mRNA and protein expression pattern during adipocyte differentiation of mice eWAT adipocytes. The levels of SFRP4 mRNA and protein increased after the treatment with inducers, and the peak expression was on day 14 (Fig. 2). 
Fig. 2. SFRP4 expression was promoted in epididymal white adipose tissue (eWAT) adipocyte differentiation (A) Photomicrographs show Oil Red 0 staining of eWAT adipocytes on day 14 of differentiation (magnification 200x). eWAT preadipocytes were grown and differentiated into mature adipocytes. Cells were harvested at the indicated time points and SFRP4 mRNA expression was measured by RT-PCR. (B) SFRP4 protein expression was measured by Western blot ( $\beta$-tubulin was used as a loading control). A representative blot and quantification of the data from three independent experiments were shown. (C) Micrographs showed Oil Red 0 staining of knockdown SFRP4 at the differentiation day 14 (magnification $200 \times$ ). The effect of SFRP4 knockdown for $72 \mathrm{~h}$ on the priming of eWAT adipocytes was assessed by RT-PCR. (D) SFRP4 protein expression was assessed by Western blot ( $\beta$-tubulin was used as a loading control). A representative blot

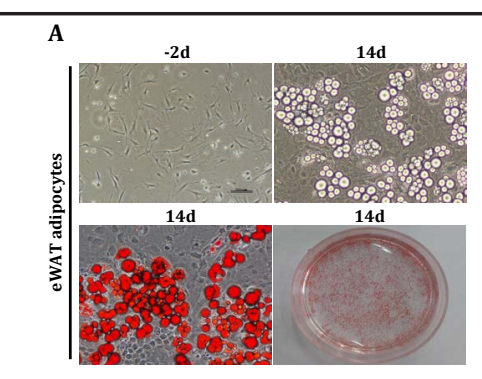

B

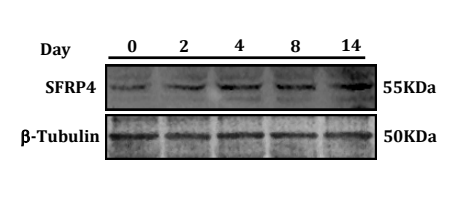

C

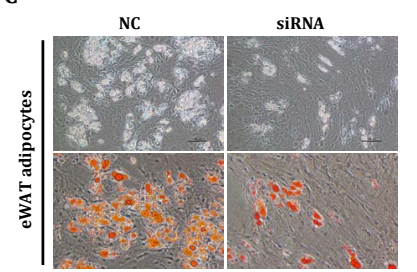

D
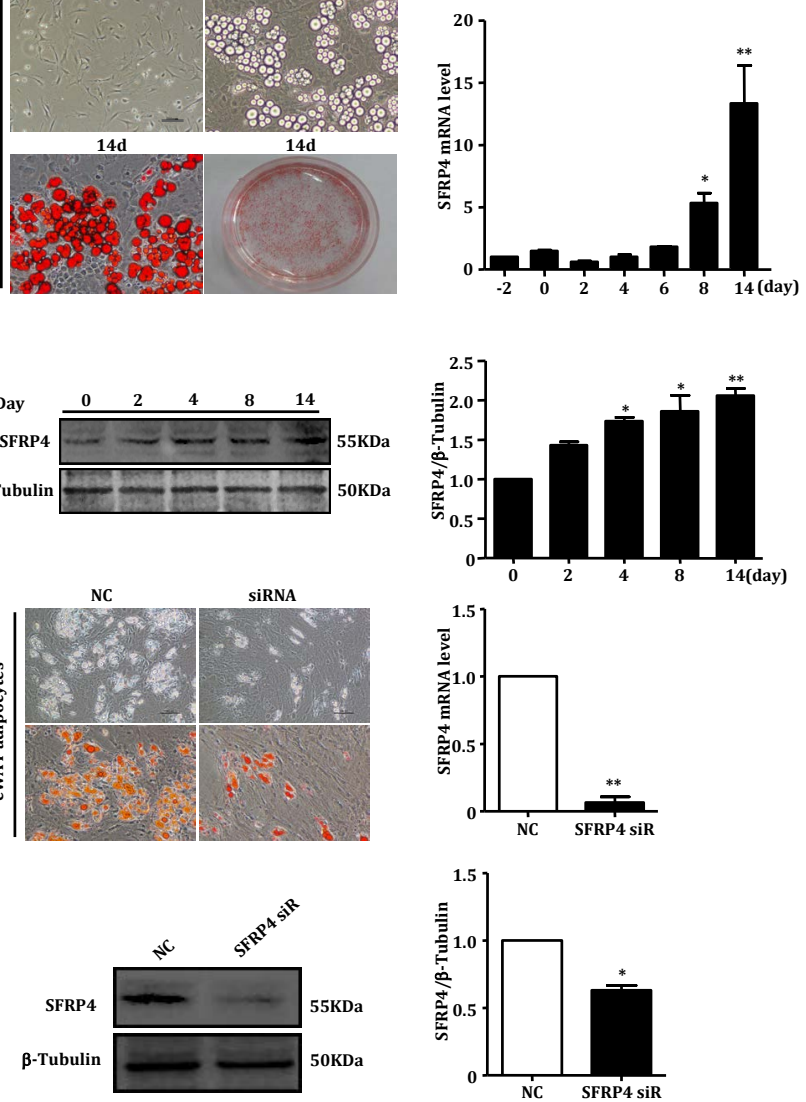
and quantification of the data from three to six independent experiments were shown. The results were expressed as fold change compared with negative control (NC) cells. Data were expressed as the means \pm SEM. $n=3-6$ independent experiments. ${ }^{*} P<0.05,{ }^{* *} P<0.01$ vs. control.

The differentiation status of eWAT adipocytes was monitored by Oil Red 0 staining, which indicated that terminal differentiation had been reached (Fig. 2).

\section{SFRP4 promoted eWAT preadipocytes differentiation}

To explore the role of SFRP4 during eWAT preadipocyte differentiation, siRNA was used to interfere with the expression of SFRP4. Knockdown was maintained throughout differentiation. The results demonstrated that SFRP4 siRNA significantly inhibited both the mRNA and protein expression of SFRP4 at $72 \mathrm{~h}$ post-transfection and induction (Fig. 2CD). SFRP4 knockdown resulted in decreased lipid accumulation throughout differentiation (Fig. 2C). Additional features of differentiating eWAT adipocytes were assessed by RTPCR and Western blotting analysis of adipogenic markers (Fig. 3). There were significant decreases in the mRNA levels of adipogenic markers, including peroxisome proliferatoractivated receptor gamma (PPAR $\gamma$ ), glucose transporter 4 (GLUT4), adiponectin, and FABP4. Analysis of the protein expression confirmed the adipogenic effects of SFRP4 knockdown. Adiponectin protein levels were significantly reduced at differentiation day 14 after SFRP4 knockdown (Fig. 3). Protein expression levels of leptin and FABP4 were not changed during the differentiation of SFRP4 knockdown cells (Fig. 3).

Furthermore, we determined the effects of SFRP4 knockdown on the expression of genes involved in the canonical Wnt pathway. SFRP4 knockdown promoted an increase in the 
Fig. 3. Silence SFRP4 inhibited eWAT adipocyte differentiation. The effect of SFRP4 knockdown of eWAT adipocytes was assessed using RT-PCR and Western blotting at differentiation day 14. (A) The mRNA expression of adiponectin; CCAAT/enhancer binding protein alpha $(\mathrm{C} / \mathrm{EBP} \alpha$; $\mathrm{C} / \mathrm{EBP} \beta$; fatty acid binding protein 4 (FABP4); facilitated glucose transporter, member 4 (GLUT4); and peroxisome proliferator activated receptor gamma (PPAR $\gamma$ were determined by RT-PCR at differentiation day 14. Results were expressed as fold change compared with NC (control) cells. (B) The mRNA expression of $\beta$-catenin, transcription factor 4 (TCF-4), cyclin D, and c-Myc were determined by RT-PCR at differentiation day 14. (C) Represen-

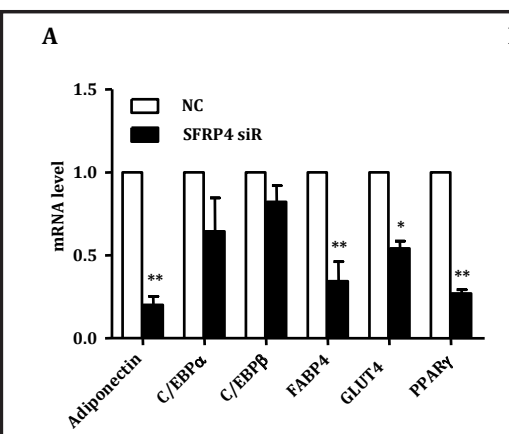

C

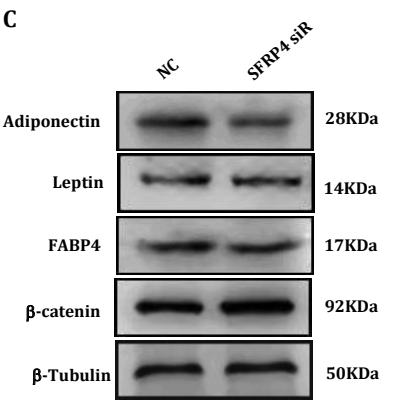

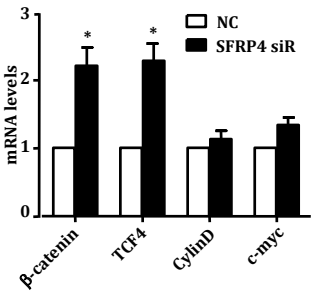

D

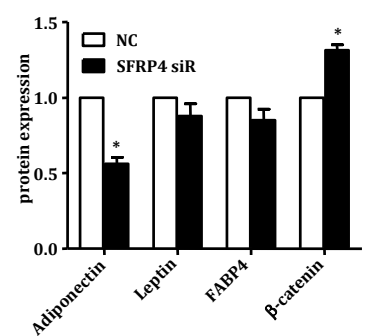
tative Western blotting of whole cell lysates showing the induction of the adipocyte proteins adiponectin, leptin, FABP4 and $\beta$-catenin at differentiation day 14 ( $\beta$-tubulin was used as a loading control). A representative blot and quantitation of data from three to six independent experiments were shown. The results were expressed as fold change compared with the NC cells. Data were expressed as the means \pm SEM. n=3-6 for each group. ${ }^{*} P<0.05,{ }^{* *} P<0.01$ vs. control.

Fig. 4. SFRP4 expression was reduced in inguinal white adipose tissue (iWAT) adipocyte differentiation. (A) Photomicrographs showed Oil Red 0 staining of iWAT adipocytes on day 2 and day 14 of differentiation (magnification $200 \times$ ). iWAT preadipocytes were grown and differentiated into mature adipocytes. Cells were harvested at the indicated time points, and SFRP4 mRNA expression was measured by RT-PCR. (B) SFRP4 protein expression was assessed by Western blot during the adipocyte differentiation ( $\beta$-tubulin was

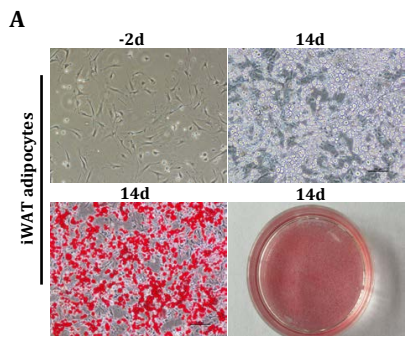

B
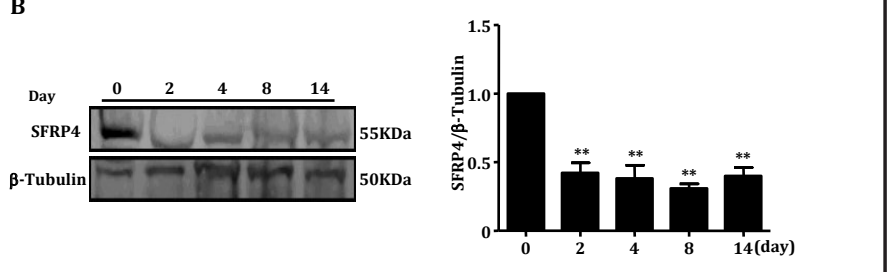
used as a loading control). A representative blot and quantification of the data from three independent experiments were shown. Data were expressed as the means \pm SEM. $n=3-6$ for each group. ${ }^{*} P<0.05$, ${ }^{* *} \mathrm{P}<0.01$ vs. control.

mRNA levels of both $\beta$-catenin and transcription factors-4 (Fig. 3). However, the knockdown exhibited no effect on downstream gene expressions (cyclin D and c-Myc) (Fig. 3). Protein expression analysis confirmed the results that $\beta$-catenin increased significantly compared to 
the control group after SFRP4 knockdown. These results suggest that the adipogenic effects of SFRP4 knockdown may be at least partly mediated by the modulation of canonical Wnt/ $\beta$ catenin signaling.

\section{Expression pattern of SFRP4 in iWAT preadipocyte differentiation}

To extend our observations, we performed similar experiments in iWAT preadipocytes. Our data showed the SFRP4 mRNA expression pattern during adipocyte differentiation of mouse iWAT adipocytes. At 2 days post-confluence, growth-arrested iWAT preadipocytes were induced into mature adipocytes. The level of SFRP4 mRNA and protein was reduced significantly after treatment with inducers from day 0 to day 14 (Fig. $4 \mathrm{~A}$ right, B). The differentiation status of iWAT adipocytes was monitored by Oil Red 0 staining, which indicated that terminal differentiation had been reached (Fig. 4A, left). As shown in Fig. 5B-C, we observed that SFRP4 siRNA treatment at day 7 significantly reduced the levels of SFRP4 mRNA and protein but exhibited no effect on cellular lipid accumulation as assessed by Oil Red 0 staining (Fig. 5A).

\section{SFRP4 knockdown altered early stage iWAT adipocyte differentiation}

The impact of SFRP4 on adipogenesis in iWAT was assessed by knockdown before the start of the differentiation, followed by mRNA expression analysis of adipogenesis-associated genes at different time points. Pivotal adipogenic transcription factors including C/EBP $\alpha, C /$ EBP $\beta$, FABP4 and GLUT4 mRNA levels were significantly increased at differentiation day 0 (Fig. 6A). On the third day of induction, only adiponectin mRNA expression level increased after SFRP4 silencing (Fig. 6B). However, after 7 days of induction, SFRP4 knockdown did not have an impact on the adipocyte differentiation phenotype (Fig. 6C), since the expression of several adipocyte marker genes including adiponectin, C/EBP $\alpha, \mathrm{C} / \mathrm{EBP} \beta, \mathrm{FABP} 4$, GLUT4, and PPAR $\gamma$ as well as cell morphology were unaltered at full differentiation (Fig. 6C); this result suggests that, at least under the present conditions, SFRP4 may not influence adipogenesis to any significant degree in iWAT adipocytes. In addition, protein expression analysis confirmed the adipogenic effects of SFRP4 knockdown. After 7 days of induced differentiation, C/EBP $\alpha$, FABP4 and leptin protein expression levels were significantly increased and remained throughout differentiation after SFRP4 knockdown (Fig. 6E-F).

Next, we tested the Wnts gene expression levels. We found that the Wnt/ $\beta$-catenin pathway of Wnt3a and Wnt7a mRNA expression levels were inhibited, but noncanonical Wnt signaling of Wnt5a and Wnt11 mRNA expression levels were promoted after SFRP4

Fig. 5. (A) Micrographs showed Oil Red 0 staining of SFRP4 knockdown at differentiation day 7 (magnification 200×). Oil Red 0 staining area was qualified after SFRP4 knockdown in iWAT adipocyte at differentiation day 7. (B) The effect of SFRP4 knockdown on differentiation day 7 of iWAT adipocyte priming was assessed using RT-PCR. (C) SFRP4 protein expression was assessed by Western blot ( $\beta$-tubulin was used as a loading control). A representative blot and quantification of the data
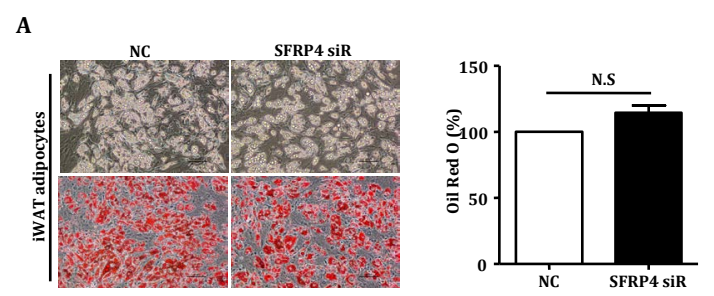

B
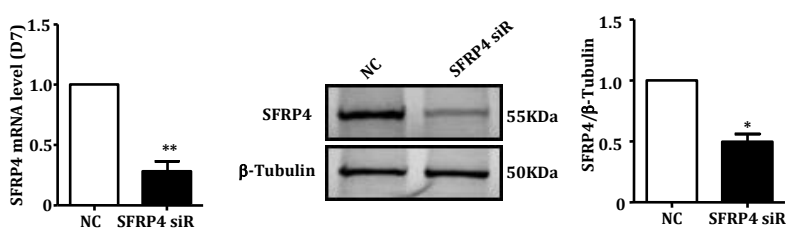
from three to six independent experiments were shown. The results were expressed as fold change compared with NC cells. Data were expressed as the means \pm SEM. $\mathrm{n}=3-6$ independent experiments. ${ }^{*} P<0.05,{ }^{* *} P<0.01$ vs. control. 
knockdown (Fig. 6D). Analysis of protein expression demonstrated that the protein expression of the Wnt/ $\beta$-catenin pathway marker $\beta$-catenin was decreased significantly compared to the control cell (Fig. 6E-F), which was consistent with the mRNA expression of Wnts (Wnt3a and Wnt7a). Thus, these observations indicated that SFRP4 may play an inhibitory role in the early stage of iWAT adipocyte adipogenesis. In particular, the changes in cell morphology and the increase in $\mathrm{C} / \mathrm{EBP} \alpha, \mathrm{C} / \mathrm{EBP} \beta$ gene expression upon SFRP4 knockdown suggest a role for SFRP4 in cell fate determination and commitment (Fig. 6).

\section{Effect of IL-1 $\beta$ on SFRP4 expression in eWAT and IWAT adipocytes}

Previously, a study demonstrated that SFRP4 expression correlated with an inflammatory marker, and its release from islets was stimulated by IL-1 $\beta$ [15] To further explore the modulatory role of IL- $\beta$ in the context of SFRP4 expression, we examined the effect of SFRP4 on the sensitivity to IL-1 $\beta$. eWAT preadipocytes were incubated with IL-1 $\beta$ during maintenance and differentiation in the presence $25 \mathrm{ng} / \mathrm{mL}$ IL-1 $\beta$. As expected, lipid accumulation was reduced by IL-1 $\beta$ (Fig. 7A). IL-1 $\beta$ had no effect on SFRP4 mRNA expression (Fig. 7B). By comparison, IL-1 $\beta$ significantly increased the inflammatory gene expression of interleukin-6 and monocyte chemotactic protein-1 (Fig. 7C). To our surprise, it significantly suppressed GLUT4, PPAR $\gamma$ and adiponectin gene expression (Fig. 7C). We also observed that IL-1 $\beta$ suppressed adiponectin protein expression (Fig. 7D-E). However, IL-1 $\beta$ had little effect on the levels of tumor-necrosis factor- $\alpha$ (TNF- $\alpha$ ), perilipin 2 and C/EBP $\alpha$ genes (Fig. 7C).

Next, we investigated IL-1 $\beta$ induced changes of the targeted genes and proteins in iWAT adipocytes. As shown in Fig. 8A, IL-1 $\beta$ treatment markedly suppressed the lipid accumulation of adipocytes. As anticipated, IL-1 $\beta$ stimulated targeted inflammatory factorgene expressions such as TNF- $\alpha$, monocyte chemotactic protein-1 and interleukin-6 (Fig. 8C). Our results showed that the mRNA or/and protein expression levels of adipogenic genes (including $\mathrm{C} /$ EBP $\alpha$, GLUT4 and PPAR $\gamma$ ) were reduced by IL-1 $\beta$ (Fig. 8C-D). Unlike eWAT adipocytes, IL-1 $\beta$

Fig. 6. SFRP4 knockdown induced iWAT adipocyte differentiation in the initial stage. The effect of SFRP4 knockdown of iWAT adipocytes was assessed using RT-PCR and Western blotting at differentiation day 7. (A, $B, C)$ mRNA expression of adiponectin, C/EBP $\alpha, \mathrm{C} / \mathrm{EBP} \beta, \mathrm{FABP} 4$, GLUT4 and PPAR $\gamma$ were determined by RTPCR at differentiation day 0,3 and 7, respectively. (D) mRNA expression of Wnt3a, Wnt5a, Wnt7a, Wnt11 were determined by RT-PCR at differentiation day 0. (E) Adiponectin, FABP4, $\mathrm{C} / \mathrm{EBP} \alpha$, leptin and $\beta$-catenin protein expression were determined by Western blot at differentiation day 7 ( $\beta$-tubulin was used as a loading control). (F) A representative blot and quantification of the data from three to six independent experiments were shown. Results were expressed as fold compared with NC cells. Data were expressed as the means \pm SEM. $\mathrm{n}=3-6$ for each group. $* P<0.05$, $* * P<0.01$ vs. control.

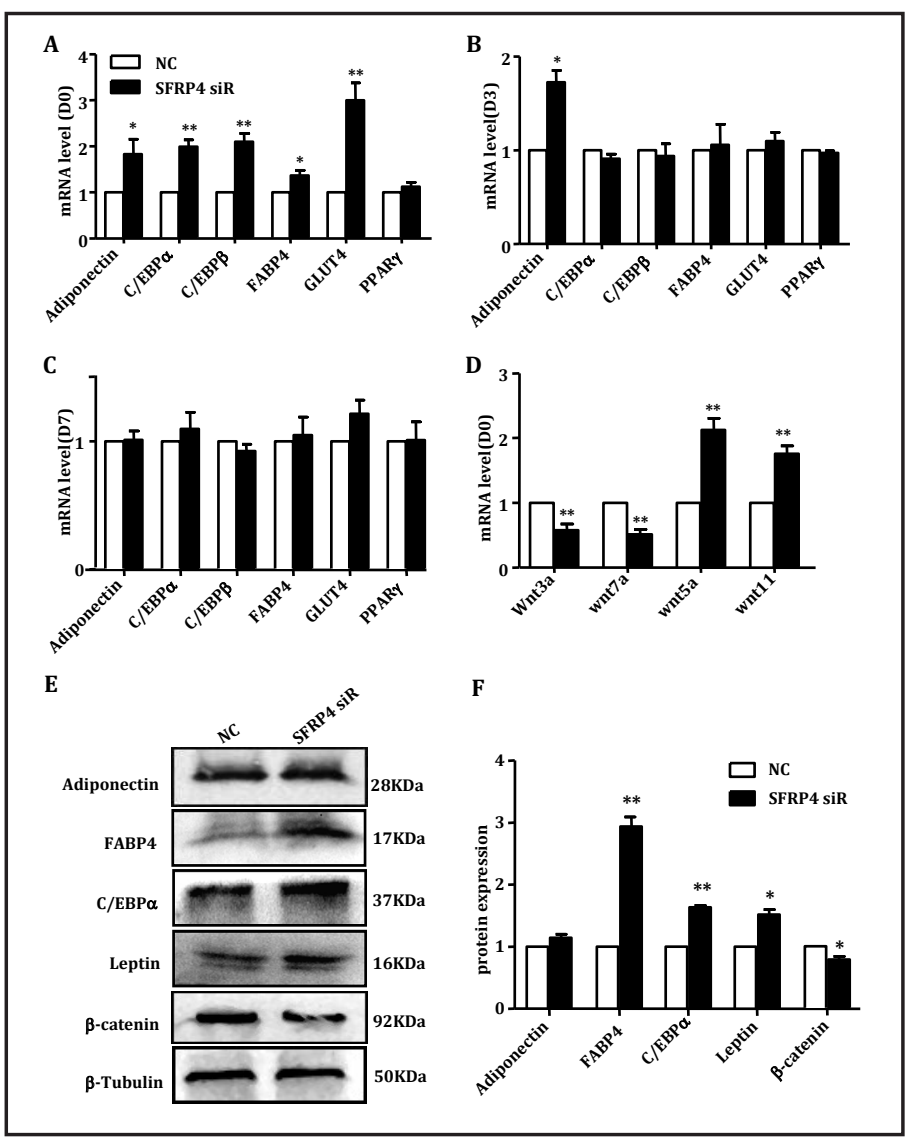


significantly reduced SFRP4 mRNA expression and increased $\alpha$-catenin protein expression compared to the control groups in iWAT adipocytes (Fig. 8B-D). Thus, these data suggested that although IL-1 $\beta$ inhibited SFRP4 expression it can exhibit an antiadipogenic function in iWAT adipocytes.

\section{Discussion}

As worldwide rates of obesity and related metabolic disorders increase, we are compelled to better understand the fundamental mechanisms underlying adipocyte formation and fat tissue expansion [21]. We and others show that the capacity of adipose tissue to generate new adipocytes is dependent on the fat depotmurine subcutaneous fat having a greater adipogenic potential than visceral adipose tissue [22]. In the current study, the inguinal depot (iWAT) was used as a representative of a subcutaneous adipose tissue (SAT) while epididymal adipose tissue (eWAT) was used as a representative for visceral adipose tissue (VAT). In addition to considering the plasticity of different parts of adipose tissue, there were significant differences between SAT and VAT adipocyte size of fat depot under energy balance stress [23]. Research showed that the small volume adipocyte ratio of SAT and omental VAT of the non diabetic patients was higher than the number of fat cells in diabetic patients with obesity. In addition, Microarray Analysis showed that internal immune cell composition of high fat diet fed mice WAT was different with chow diet mice. On the other hand, this study also found in the initial stage of obesity, gonad VAT was firstly hypertrophy, next was SAT and mesenteric VAT [24]. Another research

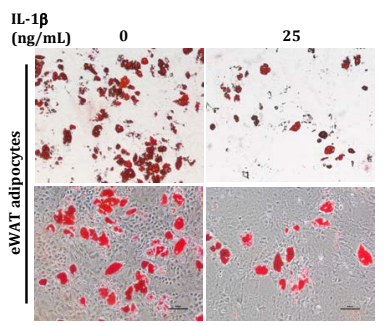

B
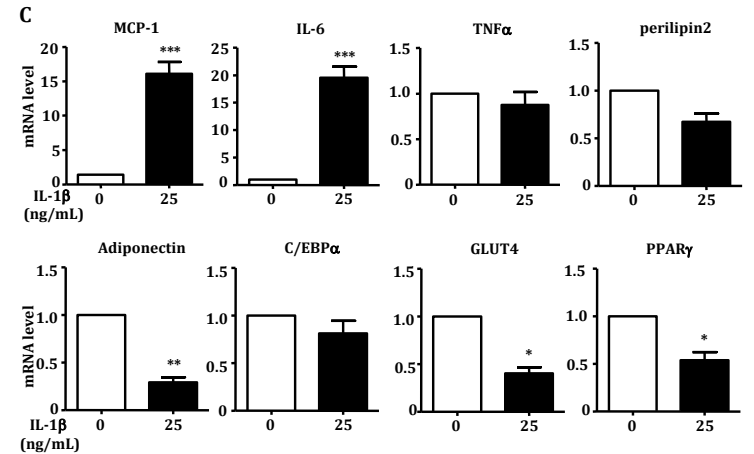

D

E
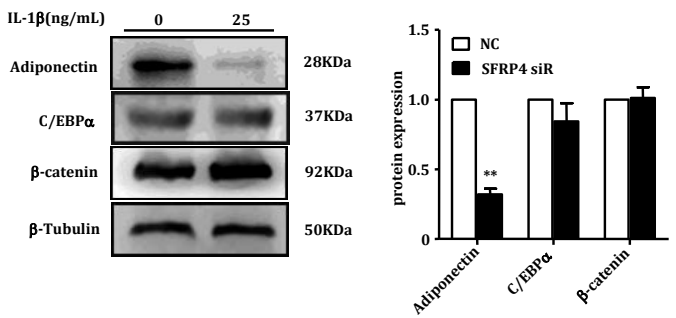

Fig. 7. eWAT preadipocytes incubated with interleukin-1 beta (IL1ß) during maintenance and differentiation. (A) Photomicrographs showed Oil Red 0 staining of cells at differentiation day 14 (magnification 200x). (B) mRNA expression of SFRP4 was assessed by RT-PCR with $25 \mathrm{ng} / \mathrm{mL}$ IL-1 $\beta$ treatment. (C) mRNA expression of inflammation markers including interleukin-6 (IL-6), monocyte chemotactic protein-1 (MCP-1), and tumor necrosis factor alpha (TNF- $\alpha$ and the adipogenic markers perilipin 2, adiponectin, C/EBP $\alpha$, GLUT4, and PPAR $\gamma$ were assessed by RT-PCR. After treatment by IL-1 $\beta$, IL- 6 and MCP-1 were 20-fold higher compared to the control group. Adiponectin, GLUT4 and PPAR $\gamma$ mRNA expression levels were decreased significantly compared to control group. (D) C/EBP $\alpha$, adiponectin and $\beta$-catenin protein expression were determined by Western blot ( $\beta$-tubulin was used as a loading control). A representative blot and quantification of the data from four independent experiments were shown. Results were expressed as fold compared with control cells. Data were expressed as the means \pm SEM. $n=4$ for each group. ${ }^{*} P<0.05$, ${ }^{* *} P<0.01$ vs. control.

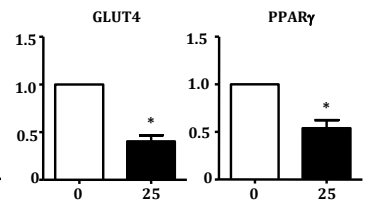


team carried out a similar experiment found that the increase of VAT fat volume was mainly caused by hypertrophy of adipocytes, while the increase of SAT was mainly achieved by cell proliferation [25]. VAT adipocytes are easier to die after terminal differentiation than SAT adipocytes. Therefore, VAT preferentially produced adipocyte hypertrophy, while SAT increases the number and activity of progenitor cells through the proliferation of adipocytes [26].

As known, RNA interference has been widely adopted to repress specific gene expression and is easily achieved by designing siRNAs with perfect sequence complementarity to the intended target mRNAs [27]. Although siRNAs direct Argonaute, a core component of the RNA-induced silencing complex, to recognize and silence target mRNAs, they also inevitably function as microRNAs and suppress hundreds of off-targets [28]. Such miRNA-like off-target repression is potentially detrimental, resulting in unwanted toxicity and phenotypes. In this experiment, we designed and synthesized three siRNA sequences according to the SFRP4 gene sequence, then we selected

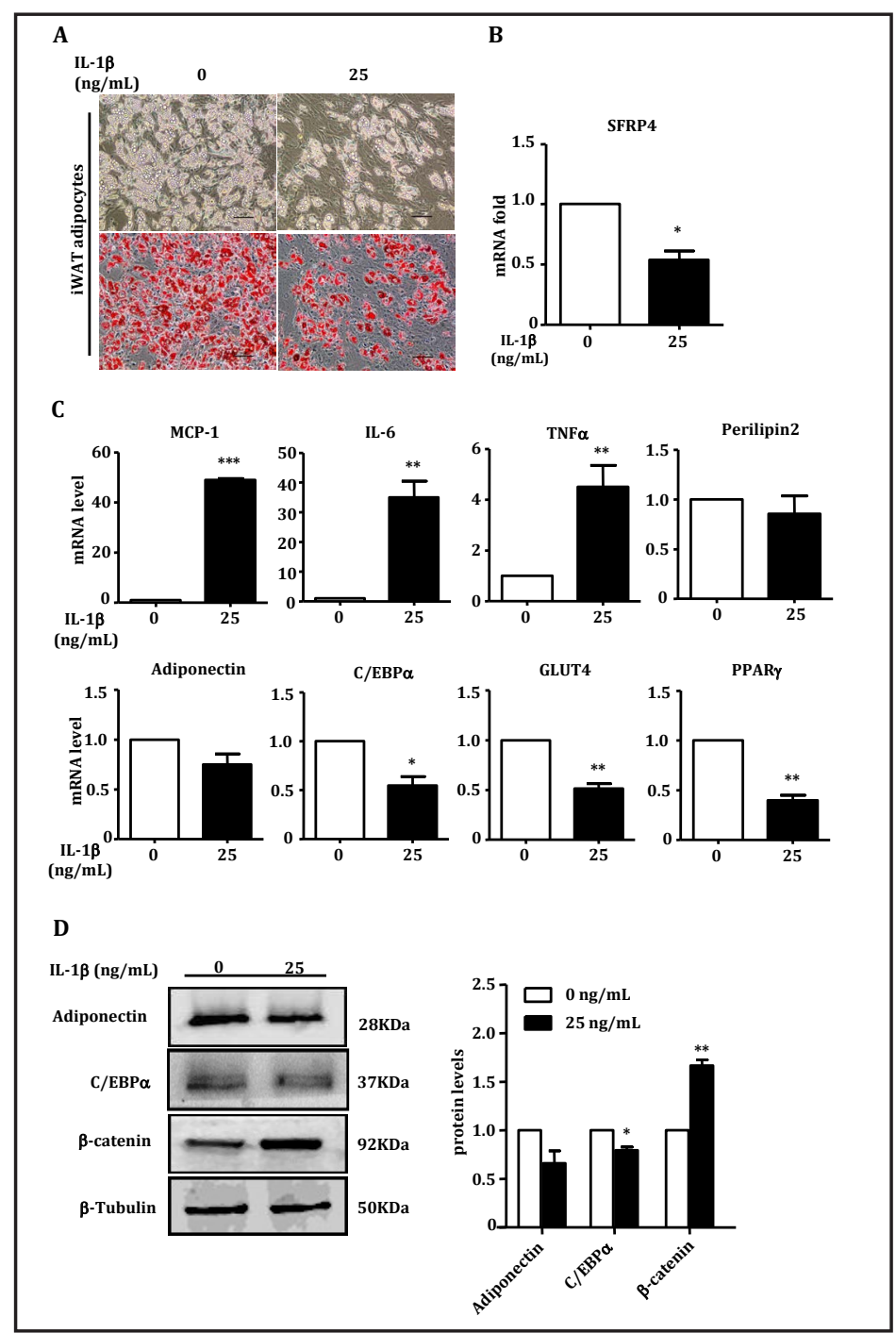

Fig. 8. iWAT preadipocytes incubated with IL-1 $\beta$ during maintenance and differentiation. (A) Photomicrographs showed Oil Red 0 staining of cells at differentiation day 7 (magnification 200×). (B) mRNA expression of SFRP4 was assessed by RT-PCR. (C) mRNA expression of the inflammatory markers IL-6, MCP-1, and TNF- $\alpha$ and the adipogenic markers perilipin 2, adiponectin, C/EBP $\alpha$, GLUT4, and PPAR $\gamma$ were assessed by RT-PCR. (D) adiponectin, C/EBP $\alpha$ and $\beta$-catenin protein expression were accessed by Western blot ( $\beta$-tubulin was used as a loading control). A representative blot and quantification of the data from four independent experiments were shown. Results were expressed as fold compared with control cells. Data were expressed as the means $\pm S E M$. $\mathrm{n}=4$ for each group. ${ }^{*} P<0.05,{ }^{* *} P<0.01$ vs. control. a best one to the follow experiment according to the interference efficiency. Secondly, the mechanism of siRNA regulation is to silence the expression of the corresponding target gene by complementing each other, so it is a typical negative regulation mechanism. siRNA is highly specific to identify target sequences, as the degradation occurs first in the central location relative to siRNA, the central base sites are extremely important. Once mismatch occurs, it will seriously inhibit siRNA effect. The designed siRNA sequence is specific to the SFRP4 gene and has no effect on the mRNA 
expression of other genes in the adipocytes. So siRNA will only complement each other with specificity of target gene, but not complement with other genes. Even if some other genes are partially combined, they all belong to mismatch, which will not lead to RNAi effect.

Several recent studies demonstrated that circulating SFRP4 levels are elevated in patients with diabetes mellitus and possibly correlated with various aspect of the metabolic syndrome [29-31], suggesting that this protein is generally involved in islet dysfunction and potentially subclinical inflammation irrespective of the type of diabetes [31]. In the present study, we demonstrated that silencing SFRP4 inhibited eWAT preadipocyte differentiation; in contrast, SFRP4 silencing promoted iWAT preadipocyte differentiation through the induction of adipocyte differentiation progression. Although SFRP4 has been shown to play an important role in several types of disease [32-34], the expression and function of SFRP4 in eWAT adipocyte development has not been fully investigated. In the current report, we first observed that SFRP4 expression was increased upon the induction of differentiation in eWAT preadipocytes. These findings led us to hypothesize that SFRP4 may be a promoter of adipogenesis and that the observed increase in SFRP4 expression may represent an integral part of the adipogenic process. To test this, we characterized the effects of SFRP4 at various stages of adipogenesis. SFRP4 knockdown resulted in the reduction of PPAR $\gamma$ and adiponectin mRNA expression; this result was consistent with the previous study $[11,12]$. Further biochemical and functional analysis revealed the reduction of adipogenesis in mature adipocytes; these findings demonstrate that SFRP4 may positively regulate adipogenesis in eWAT adipocytes.

Since its discovery as an inhibitor of Wnt/ $\beta$-catenin signaling [6], SFRP4 has been shown to play a negative role in Wnt signaling pathways $[35,36]$. The molecular mechanisms underpinning these diverse effects have, to some extent, been previously described, and recent work has added new insights [37]. In our study, the knockdown of SFRP4 increased the $\beta$-catenin and downstream transcription factors-4 mRNA expression; SFRP4 serves as a negative regulator of the canonical Wnt/ $\beta$-catenin pathway by facilitating the interaction between Wnt and its membrane receptor fizzled, a process essential for Wnt pathway activation.

In contrast to our expectations, SFRP4 knockdown in iWAT preadipocytes increased adipogenic gene expression during the induction process at the early stage of differentiation. However, at day 7 of differentiation, gene expression and lipid accumulation were not different between the control and the siRNA SFRP4 group. SFRP4 was thought to play a negative role in iWAT preadipocyte differentiation at the early stage; this result was consistent with the human primary adipocytes isolated from the iWAT [13]. Wnt3a inhibited 3T3-L1 preadipocyte differentiation [38], but Wnt5a promotes adipocyte differentiation in 3T3-L1 preadipocytes [39]; these results were consistent with our findings. Additionally, pro-inflammatory Wnt5a was not measurable in any serum samples of lean control subjects. In patients with obesity, however, Wnt5a became significantly detectable consistently with low grade inflammation in these subjects [40].

Leptin, primarily secreted by subcutaneous white adipose tissue, plays an important role in regulating energy balance and body mass [41]. Specifically, depot-specific differences in leptin gene expression have been observed in both human and rodent adipocytes [4244]. Our present data suggested that SFRP4 silencing stimulated the release of leptin in the iWAT adipocytes; however, there was no difference in leptin secretion at the late stage of adipogenesis in the eWAT adipocytes. This result was consistent with the previous study that leptin functions in lipolysis during iWAT adipocyte differentiation $[45,46]$. Furthermore, we observed no difference in the lipid accumulation of iWAT adipocytes at day 7 (Fig. 5A), which was consistent with a previous study showing that leptin inhibits the accumulation of lipid in adipocytes by increasing the turnover of triglycerides [47, 48]. Collectively, our data indicated that the knockdown of SFRP4 might increase the systemic level of leptin in the late stage of iWAT adipocyte differentiation.

A similar expression pattern was observed with adiponectin. We have shown that in the knockdown of SFRP4 in eWAT adipocytes the protein expression level of adiponectin was

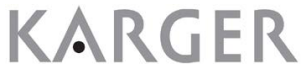




\section{Cellular Physiology Cell Physiol Biochem 2018;46:2149-2164 \begin{tabular}{c|c} 
DOI: 10.1159/000489545 & $\begin{array}{l}\text { O } 2018 \text { The Author(s). Published by S. Karger AG, Basel } \\
\text { wwww.karger.com/cpb }\end{array}$
\end{tabular} \\ Guan et al.: SFRP4 in Adipocyte Dedifferentiation}

decreased significantly in the process of differentiation, but there was no difference in iWAT adipocytes. Adiponectin is exclusively expressed by mature adipocytes, with increasing expression and secretion during the process of adipocyte differentiation, and there were higher levels of adiponectin mRNA and protein expression in the subcutaneous compared with visceral fat $[49,50]$; these results were consistent with our study. On the other hand, we found that the adiponectin mRNA expression level was consistent with PPAR $\gamma$ in the eWAT adipocyte differentiation process; these results confirmed that globular and fulllength adiponectin bind to both types of receptors and mediate the activation of PPAR $\gamma$ and, consequently, glucose uptake and fatty-acid oxidation [51]. Hence, our results revealed that SFRP4 promotes the eWAT preadipocyte differentiation possibly through the adiponectinPPAR $\gamma$ signaling pathway through inflammation associated with either obesity or insulin resistance [52]. Proinflammatory cytokines produced by adipose tissue in obesity could alter insulin signaling and action [53]. IL-1 $\beta$ decreased insulin-induced glucose transport in adipocytes mainly by inhibiting insulin receptor substrate-1 expression in 3T3-L1 cells [54]. On the other hand, a previous study demonstrated that SFRP4 expression correlated with inflammatory markers, and its release from islets was stimulated by IL-1 $\beta$ [14]. Therefore, SFRP4 provides a link between islet inflammation and impaired insulin secretion.

In the present study, after incubation with recombinant protein IL-1 $\beta$ on eWAT and iWAT adipocytes, we revealed that IL- $1 \beta$ did not promote SFRP4 mRNA expression in eWAT adipocytes, but IL-1 $\beta$ inhibited SFRP4 expression in iWAT adipocytes. Taken together, our results show that SFRP4 is a potent, positive regulator of adipogenesis in eWAT adipocytes but negatively regulated iWAT adipocyte differentiation. Accordingly, in vitro studies suggest that the expression of SFRP4 during adipocyte differentiation is very complex and varies among adipose tissues. Moreover, the findings reveal that the genes determining body size may play a dynamic role in obesity development, perhaps through depot-specific fat accumulation. In this context, our study paves the way for future research regarding distinct adipose tissue depots for elucidating cellular mechanisms in obesity.

\section{Abbreviations}

$\mathrm{Ab}$ (Antibody); C/EBP $\alpha$ (CCAAT/enhancer binding protein alpha); C/EBP $\beta$ (CCAAT/ enhancer binding protein beta); DMEM/F12 (Dulbecco's modified Eagle's medium/nutrient mixture F-12); eWAT (epididymal white adipose tissue); FABP4 (fatty acid binding protein 4); GLUT4 (solute carrier family 2 facilitated glucose transporter member 4); NC (negative control); PPAR $\gamma$ (peroxisome activated receptor gamma); SFRP4 (secreted frizzled related protein 4); siRNA (small interfering RNA); SAT (subcutaneous adipose tissue); iWAT (inguinal white adipose tissue); TNF- $\alpha$ (tumor necrosis factor alpha); IL-1 $\beta$ (interleukin-1 beta); VAT (visceral adipose tissue).

\section{Acknowledgements}

This work was supported by grants from the National Natural Science Foundation of China (81270348, 81370379) and Public Service Platform Grant from Shaanxi Province (2014FWPT-07).

\section{Disclosure Statement}

No conflict of interests exists. 


\section{Cellular Physiology Cell Physiol Biochem 2018;46:2149-2164 \begin{tabular}{l|l} 
and Biochemistry Published online: May 06, 2018 & $\begin{array}{l}\text { (c) } 2018 \text { The Author(s). Published by S. Karger AG, Basel } \\
\text { www.karger.com/cpb }\end{array}$
\end{tabular}}

\section{References}

1 Luo X, Louise J. Hutley, Webster JA, Kim Y-H, Liu D-F, Newell FS, Widberg CH, Bachmann A, Turner N, Schmitz-Peiffer C, Prins JB, Yang G-S, Whitehead JP: Identification of BMP and activin membrane-bound inhibitor (BAMBI) as a potent negative regulator of adipogenesis and modulator of autocrine/paracrine adipogenic factors. Diabets 2010;61:124-136.

-2 Kwok KH, Lam KS, Xu A: Heterogeneity of white adipose tissue: molecular basis and clinical implications. Exp Mol Med 2016;48:e215.

-3 Lee MJ, Wu Y, Fried SK: Adipose tissue heterogeneity: Implication of depot differences in adipose tissue for obesity complications. Mol Aspects Med 2013;34:1-11.

4 Mota de Sa P, Richard AJ, Hang H, Stephens JM: Transcriptional regulation of adipogenesis. Compr Physiol 2017;7:635-674.

-5 Rajesh RV, Heo GN, Park MR, Nam JS, Kim NK, Yoon D, Kim TH, Lee HJ: Proteomic analysis of bovine omental, subcutaneous and intramuscular preadipocytes during in vitro adipogenic differentiation. Comp Biochem Physiol Part D Genomics Proteomics 2010;5:234-244.

6 Leimeister C, Bach A, Gessler M: Developmental expression patterns of mouse sFRP genes encoding members of the secreted frizzled related protein family. Mech Dev 1998;75:29-42.

7 Kawano Y, Kypta R: Secreted antagonists of the Wnt signalling pathway. J Cell Sci 2003;116:2627-2634.

8 Mastaitis J, Eckersdorff M, Min S, Xin Y, Cavino K, Aglione J, Okamoto H, Na E, Stitt T, Dominguez MG, Schmahl JP, Lin C, Gale NW, Valenzuela DM, Murphy AJ, Yancopoulos GD, Gromada J: Loss of SFRP4 alters body size, food intake, and energy expenditure in diet-induced obese male mice. Endocrinology 2015;156:4502-4510.

-9 Abu-Jawdeh G, Comella N, Tomita Y, Brown LF, Tognazzi K, Sokol SY, Kocher O: Differential expression of frpHE: a novel human stromal protein of the secreted frizzled gene family, during the endometrial cycle and malignancy. Lab Invest 1999;79:439-447.

10 Li XJ, Yang H, Li GX, Zhang GH, Cheng J, Guan H, Yang GS: Transcriptome profile analysis of porcine adipose tissue by high-throughput sequencing. Anim Genet 2012;43:144-152.

11 Park JR, Jung JW, Lee YS, Kang KS: The roles of Wnt antagonists Dkk1 and sFRP4 during adipogenesis of human adipose tissue-derived mesenchymal stem cells. Cell Prolif 2008;41:859-874.

12 Visweswaran M, Schiefer L, Arfuso F, Dilley RJ, Newsholme P, Dharmarajan A: Wnt antagonist secreted frizzled-related protein 4 upregulates adipogenic differentiation in human adipose tissue-derived mesenchymal stem cells. PLoS One 2015;10:e0118005.

13 Ehrlund A, Mejhert N, Lorente-Cebrian S, Astrom G, Dahlman I, Laurencikiene J, Ryden M: Characterization of the Wnt inhibitors secreted frizzled-related proteins (SFRPs) in human adipose tissue. J Clin Endocrinol Metab 2013;98:E503-E508.

14 Liu F, Qu H, Li Y, Tang Q, Yang Z, Wang H, Deng H: Relationship between serum secreted frizzled-related protein 4 levels and the first-phase of glucose-stimulated insulin secretion in individuals with different glucose tolerance. Endocr J 2015;62:733-740.

15 Mahdi T, Hanzelmann S, Salehi A, Muhammed SJ, Reinbothe TM, Tang Y, Axelsson AS, Zhou Y, Jing X, Almgren P, Krus U, Taneera J, Blom AM, Lyssenko V, Esguerra JL, Hansson O, Eliasson L, Derry J, Zhang E, Wollheim CB, Groop L, Renstrom E, Rosengren AH: Secreted frizzled-related protein 4 reduces insulin secretion and is overexpressed in type 2 diabetes. Cell Metab 2012;16:625-633.

-16 Taneera J, Lang S, Sharma A, Fadista J, Zhou Y, Ahlqvist E, Jonsson A, Lyssenko V, Vikman P, Hansson O, Parikh H, Korsgren O, Soni A, Krus U, Zhang E, Jing XJ, Esguerra JL, Wollheim CB, Salehi A, Rosengren A, Renstrom E, Groop L: A systems genetics approach identifies genes and pathways for type 2 diabetes in human islets. Cell Metab 2012;16:122-134.

17 Church CD, Berry R, Rodeheffer MS: Isolation and study of adipocyte precursors. Methods Enzymol 2014;537:31-46.

18 Yang SJ, Xu CQ Wu JW, Yang GS: SOCS3 inhibits insulin signaling in porcine primary adipocytes. Mol Cell Biochem 2010;345:45-52.

19 Bustin SA, Benes V, Garson JA, Hellemans J, Huggett J, Kubista M, Mueller R, Nolan T, Pfaffl MW, Shipley GL, Vandesompele J, Wittwer CT: The MIQE guidelines: minimum information for publication of quantitative real-time PCR experiments. Clin Chem 2009;55:611-622. 


\section{Cellular Physiology Cell Physiol Biochem 2018;46:2149-2164 \begin{tabular}{l|l} 
DOI: 10.1159/000489545 & $\begin{array}{l}\text { O 2018 The Author(s). Published by S. Karger AG, Basel } \\
\text { www.karger.com/cpb }\end{array}$ \\
\hline
\end{tabular}

-20 Tseng YH, Kriauciunas KM, Kokkotou E, Kahn CR: Differential roles of insulin receptor substrates in brown adipocyte differentiation. Molecular and Cellular Biology 2004;24:1918-1929.

-21 Tseng YH, Kriauciunas KM, Kokkotou E, Kahn CR: Differential roles of insulin receptor substrates in brown adipocyte differentiation. Mol Cell Biol 2004;24:1918-1929.

-22 Jung HS, Lim Y, Kim EK: Therapeutic phytogenic compounds for obesity and diabetes. Int J Mol Sci 2014;15:21505-21537.

23 Meissburger B, Perdikari A, Moest H, Muller S, Geiger M, Wolfrum C: Regulation of adipogenesis by paracrine factors from adipose stromal-vascular fraction - a link to fat depot-specific differences. Biochim Biophys Acta 2016;1861:1121-1131.

-24 Meena VP, Seenu V, Sharma MC, Mallick SR, Bhalla AS, Gupta N, Mohan A, Guleria R, Pandey RM, Luthra K, Vikram NK: Relationship of adipocyte size with adiposity and metabolic risk factors in Asian Indians. PLoS One 2014;9:e108421.

-25 Joe AW, Yi L, Even Y, Vogl AW, Rossi FM: Depot-specific differences in adipogenic progenitor abundance and proliferative response to high-fat diet. Stem Cells 2009;27:2563-2570.

-26 Tchoukalova YD, Koutsari C, Votruba SB, Tchkonia T, Giorgadze N, Thomou T, Kirkland JL, Jensen MD: Sex- and depot-dependent differences in adipogenesis in normal-weight humans. Obesity (Silver Spring) 2010;18:1875-1880.

27 Anandanarayanan A, Raina OK, Lalrinkima H, Rialch A, Sankar M, Varghese A: RNA interference in Fasciola gigantica: Establishing and optimization of experimental RNAi in the newly excysted juveniles of the fluke. PLoS Negl Trop Dis 2017;11:e0006109.

28 Seok H, Lee H, Jang ES, Chi SW: Evaluation and control of miRNA-like off-target repression for RNA interference. Cell Mol Life Sci 2018;75:797-814.

-29 Hoffmann MM, Werner C, Bohm M, Laufs U, Winkler K: Association of secreted frizzled-related protein 4 (SFRP4) with type 2 diabetes in patients with stable coronary artery disease. Cardiovasc Diabetol 2014;13:155.

-30 Anand K, Vidyasagar S, Lasrado I, Pandey GK, Amutha A, Ranjani H, Mohan Anjana R, Mohan V, Gokulakrishnan K: Secreted frizzled-related protein 4 (SFRP4): a novel biomarker of beta-cell dysfunction and insulin resistance in individuals with prediabetes and type 2 diabetes. Diabetes Care 2016;39:e147-e148.

-31 Brix JM, Krzizek EC, Hoebaus C, Ludvik B, Schernthaner G, Schernthaner GH: Secreted frizzled-related protein 4 (SFRP4) is elevated in patients with diabetes mellitus. Horm Metab Res 2016;48:345-348.

-32 Jacob F, Ukegjini K, Nixdorf S, Ford CE, Olivier J, Caduff R, Scurry JP, Guertler R, Hornung D, Mueller R, Fink DA, Hacker NF, Heinzelmann-Schwarz VA: Loss of secreted frizzled-related protein 4 correlates with an aggressive phenotype and predicts poor outcome in ovarian cancer patients. PLoS One 2012;7:e31885.

33 Romaker D, Puetz M, Teschner S, Donauer J, Geyer M, Gerke P, Rumberger B, Dworniczak B, Pennekamp P, Buchholz B, Neumann HP, Kumar R, Gloy J, Eckardt KU, Walz G: Increased expression of secreted frizzledrelated protein 4 in polycystic kidneys. J Am Soc Nephrol 2009;20:48-56.

34 Bhuvanalakshmi G, Arfuso F, Millward M, Dharmarajan A, Warrier S: Secreted frizzled-related protein 4 inhibits glioma stem-like cells by reversing epithelial to mesenchymal transition, inducing apoptosis and decreasing cancer stem cell properties. PLoS One 2015;10:e0127517.

-35 Warrier S, Bhuvanalakshmi G, Arfuso F, Rajan G, Millward M, Dharmarajan A: Cancer stem-like cells from head and neck cancers are chemosensitized by the Wnt antagonist, sFRP4, by inducing apoptosis, decreasing stemness, drug resistance and epithelial to mesenchymal transition. Cancer Gene Ther 2014;21:381-388.

36 Huang YW, Gu F, Dombkowski A, Wang LS, Stoner GD: Black raspberries demethylate Sfrp4, a WNT pathway antagonist, in rat esophageal squamous cell papilloma. Mol Carcinog 2016;55:1867-1875.

-37 Drake JM, Friis RR, Dharmarajan AM: The role of sFRP4, a secreted frizzled-related protein, in ovulation. Apoptosis 2003;8:389-397.

38 Yiew NKH, Chatterjee TK, Tang YL, Pellenberg R, Stansfield BK, Bagi Z, Fulton DJ, Stepp DW, Chen W, Patel V, Kamath VM, Litwin SE, Hui DY, Rudich SM, Kim HW, Weintraub NL: A novel role for the Wnt inhibitor APCDD1 in adipocyte differentiation: implications for diet-induced obesity. J Biol Chem 2017;292:63126324.

-39 Nishizuka M, Koyanagi A, Osada S, Imagawa M: Wnt4 and Wnt5a promote adipocyte differentiation. FEBS Lett 2008;582:3201-3205. 


\section{Cellular Physiology Cell Physiol Biochem 2018;46:2149-2164

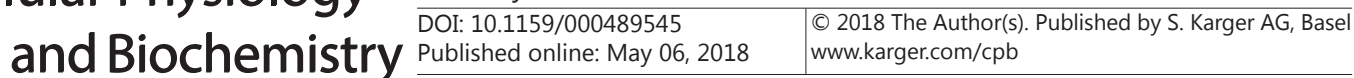 \\ Guan et al.: SFRP4 in Adipocyte Dedifferentiation}

40 Schulte DM, Muller N, Neumann K, Oberhauser F, Faust M, Gudelhofer H, Brandt B, Krone W, Laudes M: Pro-inflammatory wnt5a and anti-inflammatory sFRP5 are differentially regulated by nutritional factors in obese human subjects. PLoS One 2012;7:e32437.

41 Masuzaki H, Ogawa Y, Isse N, Satoh N, Okazaki T, Shigemoto M, Mori K, Tamura N, Hosoda K, Yoshimasa Y, et al.: Human obese gene expression. Adipocyte-specific expression and regional differences in the adipose tissue. Diabetes 1995;44:855-858.

42 Zhang Y, Guo KY, Diaz PA, Heo M, Leibel RL: Determinants of leptin gene expression in fat depots of lean mice. Am J Physiol Regul Integr Comp Physiol 2002;282:R226-R234.

-43 Rosenbaum M, Nicolson M, Hirsch J, Heymsfield SB, Gallagher D, Chu F, Leibel RL: Effects of gender, body composition, and menopause on plasma concentrations of leptin. J Clin Endocrinol Metab 1996;81:34243427.

44 Schwartz MW, Peskind E, Raskind M, Boyko EJ, Porte D, Jr.: Cerebrospinal fluid leptin levels: relationship to plasma levels and to adiposity in humans. Nat Med 1996;2:589-593.

45 Wojciechowicz T, Skrzypski M, Kolodziejski PA, Szczepankiewicz D, Pruszynska-Oszmalek E, Kaczmarek P, Strowski MZ, Nowak KW: Obestatin stimulates differentiation and regulates lipolysis and leptin secretion in rat preadipocytes. Mol Med Rep 2015;12:8169-8175.

46 Harris RB: Direct and indirect effects of leptin on adipocyte metabolism. Biochim Biophys Acta 2014;1842:414-423.

-47 Jaubert AM, Penot G, Niang F, Durant S, Forest C: Rapid nitration of adipocyte phosphoenolpyruvate carboxykinase by leptin reduces glyceroneogenesis and induces fatty acid release. PLoS One 2012;7:e40650.

48 William WN, Jr., Ceddia RB, Curi R: Leptin controls the fate of fatty acids in isolated rat white adipocytes. J Endocrinol 2002;175:735-744.

-49 Wajchenberg BL, Giannella-Neto D, da Silva ME, Santos RF: Depot-specific hormonal characteristics of subcutaneous and visceral adipose tissue and their relation to the metabolic syndrome. Horm Metab Res 2002;34:616-621.

-50 Svensson H, Oden B, Eden S, Lonn M: Adiponectin, chemerin, cytokines, and dipeptidyl peptidase 4 are released from human adipose tissue in a depot-dependent manner: an in vitro system including human serum albumin. BMC Endocr Disord 2014;14:7.

51 Kiess W, Petzold S, Topfer M, Garten A, Bluher S, Kapellen T, Korner A, Kratzsch J: Adipocytes and adipose tissue. Best Pract Res Clin Endocrinol Metab 2008;22:135-153.

52 Ding S, Lund PK: Role of intestinal inflammation as an early event in obesity and insulin resistance. Curr Opin Clin Nutr Metab Care 2011; 14:328-333.

53 Tanti JF, Ceppo F, Jager J, Berthou F: Implication of inflammatory signaling pathways in obesity-induced insulin resistance. Front Endocrinol (Lausanne) 2012;3:181.

54 Jager J, Grémeaux T, Cormont M, Le Marchand-Brustel Y, Tanti J-F: Interleukin-1 $\alpha$-induced insulin resistance in adipocytes through down-regulation of insulin receptor substrate-1 expression. Endocrinology 2007;148:241-251. 